\title{
Hormonal Stimulation of Eucaryotic Cell
}

\section{ADP-ribosylation}

\author{
EFFECT OF THYROTROPIN ON THYROID CELLS
}

\author{
Sebastiano Filetti and BASIL RAPoport, The Medical Service, Veterans' \\ Administration Hospital and the University of California Medical Center, \\ San Francisco, California 94121
}

\begin{abstract}
A B S T R A C T The effect of thyrotropin (TSH) on the ADP-ribosylation of endogenous thyroid cell acceptor proteins was examined. Cells were "permeabilized" at $4^{\circ} \mathrm{C}$ in hypotonic medium and then exposed to $\left.{ }^{32} \mathrm{P}\right]-$ or $\left[{ }^{3} \mathrm{H}\right.$-adenine $] \mathrm{NAD}^{+}$. The net incorporation of labeled ADP-ribose was measured by trichloroacetic acid precipitation. TSH $(100 \mathrm{mU} / \mathrm{ml})$ enhanced ADPribosylation with a maximum effect after 30-60 min in the majority of experiments. TSH stimulation was observed even when the incubation contained 1,000-fold more exogenous $\mathrm{NAD}^{+}$than the amount of $\mathrm{NAD}^{+}$contributed by the permeabilized cells, indicating an effect on enzymatic activity rather than an alteration in $\mathrm{NAD}^{+}$pool size or specific activity. No incorporation of radioactivity from labeled $\mathrm{NAD}^{+}$was observed in cells not rendered permeable to $\mathrm{NAD}^{+}$by hypotonic shock. TSH did not increase the rate of disappearance of trichloroacetic-precipitable radioactivity and did not contain intrinsic $\mathrm{NAD}^{+}$glycohydrolase activity. Alkali and snake venom phosphodiesterase, but not ribonuclease or deoxyribonuclease digestion of trichloroacetic acid precipitable thyroid cell radioactivity, revealed primarily $5^{\prime}$-AMP, consistent with an effect of TSH on mono-ADP ribosylation. Nicotinamide and thymidine $(50 \mathrm{mM})$ inhibited both basal and TSHstimulated ADP-ribosylation of thyroid cell protein. Dibutyryl cyclic (c)AMP $(0.1 \mathrm{mM})$ inhibited endogenous ADP-ribosylation by $\sim 35 \%$ but had no effect at lower concentrations. $0.5 \mathrm{mM}$ isobutylmethylxanthine inhibited this reaction by $\sim 60 \%$.
\end{abstract}

Dr. Filetti is an International Fellow of the Fulbright Foundation and visiting scientist from the University of Catania, Italy.

Address reprint requests to Dr. Rapoport, Medical Service (111F), Veterans' Administration Hospital, 4150 Clement St., San Francisco, Calif. 94121.

Received for publication 29 December 1980 and in revised form 17 April 1981.
We suggest that TSH enhances thyroid cell ADPribosylation by a mechanism independent of cAMP as a second messenger, and that ADP-ribosylation plays a role in the expression of TSH.

\section{INTRODUCTION}

Previous studies from this laboratory have provided evidence that the desensitization of cultured thyroid cells to thyrotropin (TSH) ${ }^{1}$ stimulation of cyclic (c)AMP generation is $\mathrm{NAD}^{+}$dependent, and possibly related to mono- or poly-ADP-ribosylation of unknown thyroid cell acceptor proteins. Thus nicotinamide prevented desensitization to TSH (1). In addition, thymidine, bromodeoxyuridine, bromouridine, and methyl analogues of nicotinamide, all of which are inhibitors of poly(ADP-ribose)polymerase activity (2-4), and some of which inhibit mono-ADP-ribosylation (5), similarly blocked TSH desensitization (6). After removal of TSH from cultured thyroid cells, recovery from TSH desensitization was extremely slow (incomplete after $72 \mathrm{~h}$ ) and hastened by nicotinamide, indicating further that the desensitization process involved the covalent modification of cellular molecules rather than changes in rapidly turning-over substances such as various ions and nucleotides (6).

While the poly-ADP-ribosylation reaction is known to play a role in DNA replication and repair (7-9), it has been speculated that poly-, and perhaps monoADP-ribosylation may be important in regulating a much wider variety of cellular functions. Evidence to support this concept has been elusive. Eucaryotic poly(ADP-ribose)polymerase (7) and mono(ADP-ribose) transferase (5) have been highly purified and shown to ADP-ribosylate numerous acceptor proteins. How-

\footnotetext{
${ }^{1}$ Abbreviations used in this paper: $\mathrm{Bt}_{2} \mathrm{cAMP}$, dibutyryl cAMP; TSH, thyrotropin.
} 
ever, the physiological significance of these reactions remains poorly understood. This contrasts with the well-known pathological role of ADP-ribosylation reactions in the mediation of bacterial toxin actions on eucaryotic cells $(10,11)$. In our study we have demonstrated that TSH stimulates ADP-ribosylation of endogenous substrate in intact permeabilized thyroid cells. The data support the previously obtained evidence of a role for the ADP-ribosylation process in TSH desensitization.

\section{METHODS}

Thyroid cell preparation. Dog thyroids $(1.5-3 \mathrm{~g})$ were obtained fresh from animals sacrificed for other reasons. Dispersed thyroid follicles were obtained as described (12), except that slices were chopped at $300 \mu \mathrm{m}$, collagenase digestion was in $\mathrm{Ca}^{++}$and $\mathrm{Mg}^{++}$-free saline, and liberated follicles were separated from tissue chunks by sedimentation at $1 \mathrm{~g}$. Dispersed follicles were rinsed free of collagenase with Puck's saline A (two washes at $100 \mathrm{~g}$ for $5 \mathrm{~min}$ ), and then stored on ice until use a few minutes later. Thyroid cell number could not be counted because of their association in follicles, but cellular protein was determined by the method of Lowry et al. (13), using bovine serum albumin as standard.

ADP-ribosylation assay. The hypotonic shock method of Skidmore et al. (14) for intact cells, based on previous methods $(3,15)$, was used with minor modifications. Thyroid cells from $1.5-3 \mathrm{~g}$ of tissue were centrifuged for $5 \mathrm{~min}$ at $100 \mathrm{~g}$, suspended in $1.3 \mathrm{ml}$ hypotonic buffer $(9 \mathrm{mM}$ Hepes, pH 7.8, $5 \mathrm{mM}$ dithiothreitol, $1 \mathrm{mM}$ EGTA, $4.5 \mathrm{mM} \mathrm{MgCl}_{2}$ $4.5 \%$ dextran), and maintained at $4^{\circ} \mathrm{C}$ for $30 \mathrm{~min}$. This hypotonic shock procedure makes the cells permeable to subsequently added substances, such as $\mathrm{NAD}^{+}$, which normally enter intact cells with difficulty. The cells were then diluted $1: 10$ in a second buffer, $\mathrm{pH} 7.8$, containing $40 \mathrm{mM}$ Hepes, $2.5 \mathrm{mM}$ dithiothreitol, $130 \mathrm{mM} \mathrm{KCl}, 2 \mathrm{mM}$ EGTA, $2.3 \mathrm{mM}$ $\mathrm{MgCl}_{2}, 222 \mathrm{mM}$ sucrose, $4 \%$ dextran, $\left[{ }^{32} \mathrm{P}_{\mathrm{NAD}}{ }^{+}\right.$or $\left[{ }^{3} \mathrm{H}\right]-$ $\mathrm{NAD}^{+}\left(1-2 \times 10^{6} \mathrm{cpm} / 0.2 \mathrm{ml}\right)$, and $\mathrm{NAD}^{+}$to achieve the final concentrations indicated for each experiment. In initial experiments the buffer also included $1 \mathrm{mM} \mathrm{ATP}, 6.6 \mathrm{mg} / \mathrm{ml}$ creatine phosphokinase, and $20 \mathrm{mM}$ creatine phosphate. This ATP-regenerating system was omitted in later experiments because it did not influence the results obtained. Care was taken to ensure that the buffering capacity of this solution was sufficient for the various agents included, such as dibutyryl $\left(\mathrm{Bt}_{2}\right)$ cAMP. The reaction $(0.2 \mathrm{ml}$ final volume) was begun by warming to $25^{\circ} \mathrm{C}$. After the indicated periods of time the reaction was stopped with $3 \mathrm{ml}$ of $10 \%$ trichloroacetic acid. The precipitates were collected on $24 \mathrm{~mm}$ Diam GFC filters using an Amicon Vacuum Filtration Manifold. The filters were washed once with absolute ethanol and six times with $10 \%$ trichloroacetic acid. After drying, the filters were treated with $0.4 \mathrm{ml}$ of NCS (Amersham, Arlington Heights, Ill.) for $30 \mathrm{~min}, 8 \mathrm{ml}$ of Scintiverse (Fisher Scientific Co., Pittsburgh, Pa.) was added and the samples were then counted on a liquid scintillation counter.

Identification of the digestion products of trichloroacetic acid-insoluble material derived from labeled $\mathrm{NAD}^{+}$. Cells permeabilized as described above were incubated in the presence of ${ }^{32} \mathrm{P}^{2} \mathrm{NDD}^{+}$or $\left[{ }^{3} \mathrm{H}\right] \mathrm{NAD}{ }^{+}$for $45 \mathrm{~min}$. The reaction was stopped by adding $50 \mathrm{ml}$ of $10 \%$ ice-cold trichloroacetic acid. The precipitate was collected by centrifugation $(3,000 \mathrm{~g}$ for $20 \mathrm{~min})$. To eliminate possible contamination with free $\left.{ }^{32} \mathrm{P}\right] \mathrm{NAD}{ }^{+}$, the precipitates were washed six times with $200 \mathrm{vol}$ of $10 \%$ trichloroacetic acid and twice with 99\% ethanol. Between each wash the pellet was dispersed by sonication. For the high-pressure liquid chromatography studies, the trichloroacetic acid-insoluble radioactive material was solubilized in $200 \mu \mathrm{l} 0.1 \mathrm{~N} \mathrm{NaOH}$ for $4 \mathrm{~h}$ at $37^{\circ} \mathrm{C}$. After neutralization, samples $(100 \mu \mathrm{l})$ were treated with $40 \mu \mathrm{g}$ of snake venom phosphodiesterase (5'-nucleotidase-free) in the presence of $50 \mathrm{mM}$ Tris- $\mathrm{HCl}(\mathrm{pH} 7.8) 10 \mathrm{mM} \mathrm{MgCl}$, and $1 \mathrm{mM}$ AMP (total vol $300 \mu \mathrm{l}$ ) for $2 \mathrm{~h}$ at $37^{\circ} \mathrm{C}$. The digested products were centrifuged in a Beckman Microfuge $(10,000 \mathrm{~g})$ (Beckman Instruments, Inc., Fullerton, Calif.) for 3 min and portions $(50 \mu \mathrm{l})$ were subjected to high-performance liquid chromatography (see below).

For studies (see Table II) in which the radiolabeled material was subjected to digestion with phosphodiesterase, ribonuclease, or deoxyribonuclease without prior solubilization of the precipitate in $\mathrm{NaOH}$, the trichloroacetic acid was extracted six times with 20 vol of water-saturated ether and the sample was then evaporated to dryness. The material was then resuspended by sonication in $50 \mathrm{mM}$ Tris- $\mathrm{HCl}$ (pH 7.4) containing $10 \mathrm{mM} \mathrm{MgCl}_{2}$. Where indicated, the incubations contained $20 \mu \mathrm{g}$ ribonuclease, deoxyribonuclease, or snake venom phosphodiesterase in a final volume of $0.2 \mathrm{ml}$. The reactions $\left(37^{\circ} \mathrm{C}\right)$ were stopped at the indicated times with $1 \mathrm{ml}$ of $10 \%$ trichloroacetic acid. After centrifugation at $10,000 \mathrm{~g}$ for $4 \mathrm{~min}$ in a Beckman Microfuge, an aliquot $(0.5 \mathrm{ml})$ of the supernate in Scintiverse was counted for radioactivity.

ADP-ribosylation by cholera toxin. The procedure was a modification (16) of that of Moss and Vaughan (17). Cholera toxin $(100 \mu \mathrm{g})$ was incubated for $12 \mathrm{~h}$ at $37^{\circ} \mathrm{C}$ in $400 \mathrm{mM}$ potassium phosphate, $\mathrm{pH} 7.0$, containing $20 \mathrm{mM}$ dithiothreitol, $75 \mathrm{mM}$ L-arginine, and $6 \mathrm{mM} \mathrm{NAD}{ }^{+}$in a final volume of $0.5 \mathrm{ml}$. After centrifugation the supernate was subjected to high-performance liquid chromatography, as described below.

High-performance liquid chromatography. The reaction mixtures described above, to which internal standards were added, were chromatographed on a C18- $\mu$ Bondapak column $(30 \mathrm{~cm} \times 4 \mathrm{~mm}$; Waters Associates, Milford, Mass.) using a Waters Associates M-6000 A solvent Delivery System, V6K injector, and series 440 ultraviolet absorbance detector $(254 \mathrm{~nm})$. The mobile phase was $5 \mathrm{mM}$ tetrabutylammonium phosphate with methanol concentrations and flow rates as indicated in the text.

Materials. Tissue culture media were obtained from the University of California, San Francisco, Cell Culture Facility. Bovine TSH (Thytropar) was from Armour Pharmaceutical Co., Phoenix, Ariz.; [adenine-2,8 ${ }^{3} \mathrm{H}$ ]NAD ${ }^{+}(1-5 \mathrm{Ci} / \mathrm{mmol})$ and [adenylate- ${ }^{32} \mathrm{P}_{\mathrm{N}} \mathrm{ND}^{+}(10-50 \mathrm{Ci} / \mathrm{mmol})$ were from New England Nuclear, Boston, Mass.; tetrabutyl ammonium phosphate (reagent PIC-A) was obtained from Waters Associates. Snake venom phosphodiesterase (Crotalus adamanteus) free of $5^{\prime}$ nucleotidase, and highly purified ribonuclease I (bovine pancreas; catalogue number 05679) were purchased from Worthington Biochemical Corporation, Freehold, N. J. Highly purified bovine TSH (30 U/mg protein) was kindly supplied by Dr. J. Pierce, University of California, Los Angeles. All other reagents, including deoxyribonuclease I (bovine pancreas; DN-CL), were purchased from the Sigma Chemical Co., St. Louis, Mo.

\section{RESULTS}

Effect of TSH on ADP-ribosylation of endogenous thyroid substrate. In 16 experiments using cells from different dog thyroid glands, TSH stimulated ADP- 
ribosylation of endogenous thyroid substrate. In the experiment shown (Fig. 1), TSH $(100 \mathrm{mU} / \mathrm{ml})$ stimulation of the net formation of trichloroacetic acid-insoluble radioactivity from $\left[{ }^{32} \mathrm{P}\right] \mathrm{NAD}^{+}$was apparent after $20 \mathrm{~min}$ of incubation. The degree of TSH stimulation was similar at widely different $\mathrm{NAD}^{+}$substrate concentrations $(1 \mu \mathrm{M}$ and $1 \mathrm{mM})$. In the majority of experiments, maximum accumulation of acid-precipitable radioactivity occurred between 30 and $60 \mathrm{~min}$. In two of seven experiments maximum TSH stimulation occurred after $15 \mathrm{~min}$ of incubation and then declined even more rapidly than did control values. In support of the previously demonstrated validity of the assay in measuring endogenous ADP-ribosylation, similar kinetics of accumulation of trichloroacetic acid-precipitable material was observed with $\left[{ }^{3} \mathrm{H}\right]-$ $\mathrm{NAD}^{+}$labeled in the adenine ring and $\left[{ }^{32} \mathrm{P}\right] \mathrm{NAD}^{+}$. As validation of the effectiveness of the hypotonic shock process in making the cells permeable to $\mathrm{NAD}^{+}$,

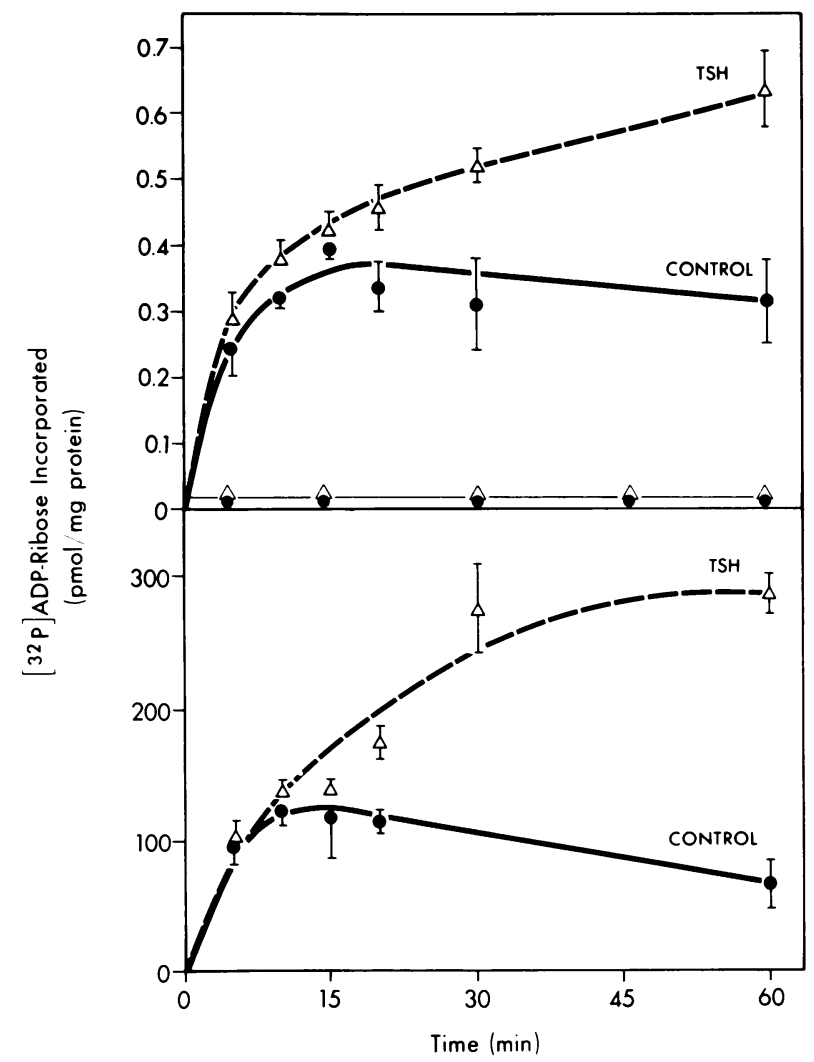

Figure 1 Time-course of incorporation of [ $\left.{ }^{32} \mathrm{P}\right]$ ADP-ribose into thyroid cellular protein. Cells ( $1.54 \mathrm{mg}$ protein/tube) were incubated in the presence or absence of $100 \mathrm{mU} / \mathrm{ml}$ TSH as described in Methods. The incubation medium contained either $\sim 1 \mu \mathrm{M} \mathrm{NAD}{ }^{+}$(upper panel; based on the contributions of the isotope and endogenous cellular $\mathrm{NAD}^{+}$) or was supplemented with $\mathrm{NAD}^{+}$to a final concentration of $1 \mathrm{mM}$ (lower panel). Each point represents the mean $\pm S E$ of triplicate determinations. the addition of $\left.{ }^{32} \mathrm{P}\right] \mathrm{NAD}^{+}$to cells not subjected to hypotonic shock (Fig. 1), or 30 min after recovery from hypotonic shock (data not shown), resulted in no observable cellular incorporation of radioactivity. To confirm that bovine TSH and not an impurity in the preparation was responsible for the observed stimulation of ADP-ribosylation, the effectiveness of impure TSH (Thytropar) was compared with that of highly purified TSH. Both preparations induced similar stimulation (Table I).

There is preliminary evidence that $\mathrm{TSH}$ preparations are contaminated with $\mathrm{NAD}^{+}$glycohydrolase activity (18). $\mathrm{NAD}^{+}$hydrolysis by this means could lead to nonenzymatic formation of radioactive Schiff-base adducts of ADP-ribose to lysine residues without an effect on thyroid cell enzyme activity. To examine further this possibility, TSH was incubated with $\left[{ }^{32} \mathrm{P}\right]-$ $\mathrm{NAD}^{+}$under conditions identical to those shown in Fig. 1, with the exception that no thyroid cells were present. As determined by high performance liquid chromatography of the reaction mixture, after $1 \mathrm{~h}$ no free ADP-ribose was produced, indicating the absence of detectable $\mathrm{NAD}^{+}$-glycohydrolase activity. Similar data were found after 5- or 24-h incubations, and in the presence of TSH concentrations as high as $1 \mathrm{U} / \mathrm{ml}$ (data not shown). As validation of the system used to analyze the reaction products, cholera toxin incubated with $\left[{ }^{3} \mathrm{H}\right] \mathrm{NAD}^{+}$and $75 \mathrm{mM}$ arginine, under optimum conditions (17), generated free ADP-ribose and ADPribose arginine, as reported $(16,17)$. Examination of $\mathrm{TSH}$ for intrinsic $\mathrm{NAD}^{+}$-glycohydrolase activity under these conditions also proved negative.

Analysis of radioactive material incorporated into thyroid cells from labeled $\mathrm{NAD}^{+}$. To determine whether TSH was stimulating incorporation of monoor poly-ADP-ribose into endogenous thyroid cell substrate, high-performance liquid chromatography analysis was performed on digestions of the trichloro-

TABLE I

Comparison of Impure and Highly Purified TSH on $\left.{ }^{32} P\right] A D P$-ribose Incorporation into Thyroid Cellular Protein

\begin{tabular}{|c|c|c|c|}
\hline \multirow[b]{2}{*}{ TSH } & \multicolumn{3}{|c|}{ Time $\min$} \\
\hline & 0 & 15 & 30) \\
\hline $100 \mathrm{mU} / \mathrm{ml}$ & & \multicolumn{2}{|c|}{ pmol ADP-riboselmg protein } \\
\hline None & 0 & $0.47 \pm 0.08^{*}$ & $0.76 \pm 0.01$ \\
\hline Partially purified TSH $\ddagger$ & - & $0.73 \pm 0.02$ & $1.31 \pm 0.15$ \\
\hline Highly purified TSH\$ & - & $0.75 \pm 0.05$ & $1.32 \pm 0.29$ \\
\hline
\end{tabular}

* Mean $\pm \mathrm{SD}$ of triplicate determinations; $1 \mathrm{mM} \mathrm{NAD}{ }^{+} ; 1.0$ mg cell protein/tube.

$\$$ Thytropar; $\sim 1 \mathrm{U} / \mathrm{mg}$ protein.

$\S$ Approximately $30 \mathrm{U} / \mathrm{mg} /$ protein. 
acetic acid-precipitable material. After a 30 -min incubation in the presence of $1 \mathrm{mM}{ }^{32} \mathrm{P} \mathrm{NAD}^{+}$, thyroid cells previously subjected to the hypotonic shock procedure incorporated more radioactivity in the presence than in the absence of $100 \mathrm{mU} / \mathrm{ml} \mathrm{TSH}$. After extensive washing in trichloroacetic acid and ethanol the pellets were solubilized in $0.1 \mathrm{~N} \mathrm{NaOH}$ and were treated with snake venom phosphodiesterase as described in Methods. In four experiments, including one at $1 \mu \mathrm{M} \mathrm{NAD}^{+}$, the primary (and in two experiments the only) product was 5'-AMP (Fig. 2). This peak was greater in the TSH-treated than in the control cells. A small amount of radioactive material

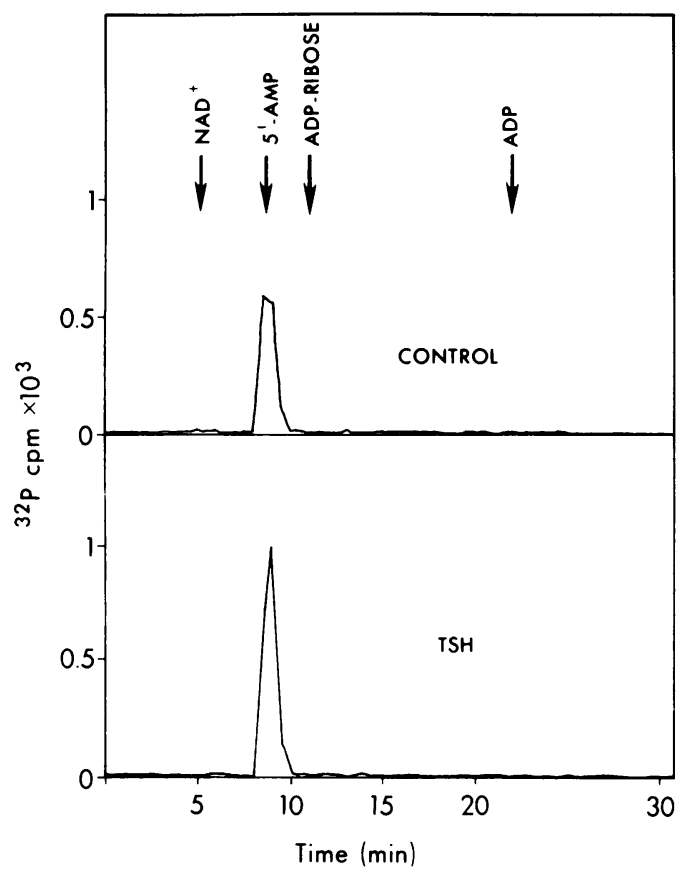

FIGURE 2 High-pressure liquid chromatography of the digestion products of radiolabeled material incorporated into thyroid cells from radiolabeled $\mathrm{NAD}^{+}$. Trichloroacetic acidinsoluble radiolabeled material obtained by incubating permeabilized cells for $45 \mathrm{~min} 1 \mathrm{mM}\left[{ }^{32} \mathrm{P}^{2} \mathrm{NAD}^{+}\right.$in the presence or absence of $100 \mathrm{mU} / \mathrm{ml} \mathrm{TSH}$ was subjected to alkali and phosphodiesterase treatment as described in Methods. Recovery of soluble radioactivity for analysis was $>95 \%$ (see Table III). Equal aliquots $(50 \mu \mathrm{l})$ from "control" (no TSH; top panel) and from TSH-treated cells (bottom panel) were chromatographed on a C18- $\mu$ Bondapak column (Waters Associates, Inc., Milford, Mass.) after the inclusion of internal, unlabeled standards (total volume injected $110 \mu \mathrm{l}$ ). The mobile phase was $5 \mathrm{mM}$ tetrabutylammonium phosphate and $20 \%$ methanol; the flow rate was $1.2 \mathrm{ml} / \mathrm{min}$. Total radioactivity in the 5'-AMP peak in the digestion from cells not stimulated with TSH (upper panel) was $1,252 \mathrm{cpm}$, and in the TSH-treated cells (lower panel) was $1,764 \mathrm{cpm}$. Recovery of injected radioactivity was $>95 \%$ in both instances. This increment in 5'AMP induced by TSH $(40.9 \%)$ was similar to the degree of TSH stimulation (44\%) in trichloroacetic acid insoluble material, measured before digestion.
( $10 \%$ of total) was inconsistently observed in a position corresponding to the expected location of phosphoribosyl-AMP (19), an unequivocal digestion product of poly(ADP-ribose). No augmentation with TSH was observed.

Because $0.1 \mathrm{~N} \mathrm{NaOH}$ could itself hydrolyse any residual "contaminating" $\mathrm{NAD}^{+}$into 5 '-AMP, the efficacy of the washing procedure was monitored. With the eight washes, with interspersed sonication of the pellet, no radioactivity was detected in the supernate on the third wash and there was therefore no soluble radioactivity left to analyze. This possibility of $\mathrm{NAD}^{+}$contamination was therefore excluded.

An additional possible artifact was that TSH was stimulating the incorporation into RNA of $\left[{ }^{32} \mathrm{P}\right]$ released by radiolabeled $\mathrm{NAD}^{+}$degradation. Digestion of this material would yield 3'- or 2'-AMP which would not be distinguishable from 5'-AMP under our highperformance liquid chromatography conditions (see above). Thyroid cellular protein radiolabeled following incubation with $\left[{ }^{32} \mathrm{P}\right] \mathrm{NAD}^{+}$was therefore subjected to ribonuclease digestion (Table II). Release of acidinsoluble material was small ( $18 \%$ after $3 \mathrm{~h}$ ) and was no greater than in the absence of ribonuclease. In contrast, phosphodiesterase or $\mathrm{NaOH}$ treatment each independently yielded $\sim 95 \%$ acid-insoluble radioactivity after $3 \mathrm{~h}$. The foregoing data therefore strongly suggested that TSH stimulated predominantly monoADP-ribosylation of endogenous thyroid substrate.

Effect of nicotinamide and thymidine on TSHstimulated ADP-ribosylation. Nicotinamide and thymidine are potent inhibitors of poly(ADP-ribose)polymerase and $\mathrm{NAD}^{+}$glycohydrolase activity. As mentioned previously, these agents (at $50 \mathrm{mM}$ ) also prevent TSH desensitization in cultured thyroid cells (6). Simi-

TABLE II

Digestion of Acid-insoluble ${ }^{32} P$-labeled Thyroid Cellular Protein

\begin{tabular}{lcccc}
\hline & \multicolumn{4}{c}{ Generation of acid-soluble ${ }^{32}$ P-labeled material } \\
\cline { 2 - 5 } \multicolumn{1}{c}{ Additives } & \multicolumn{2}{c}{$1 \mathrm{~h}$} & \multicolumn{2}{c}{$3 \mathrm{~h}$} \\
\hline & $c p m$ & $\%$ released & $c p m$ & $\%$ released \\
None & 645 & 11.1 & 1,515 & 26.0 \\
Ribonuclease & 458 & 7.9 & 1,040 & 17.8 \\
Deoxyribonuclease & 679 & 11.6 & 1,500 & 25.7 \\
Venom phospho- & & & & \\
$\quad$ diesterase & 3,098 & 53.1 & 5,490 & 94.1 \\
0.1 N NaOH & 5,678 & 97.3 & 5,633 & 96.6 \\
\hline
\end{tabular}

Permeabilized thyroid cells from $1.4 \mathrm{~g}$ of thyroid tissue were exposed to $1 \mu \mathrm{M}\left[^{32} \mathrm{P}\right] \mathrm{NAD}{ }^{+}$for $35 \mathrm{~min}$ at $37^{\circ} \mathrm{C}$ as described in Methods. Aliquots $(5,834 \mathrm{cpm})$ of trichloroacetic acid-insoluble ${ }^{32} \mathrm{P}$-labeled thyroid cellular protein were incubated for 1 or $3 \mathrm{~h}$ at $37^{\circ} \mathrm{C}$ with the indicated agents, and were then reprecipitated with trichloroacetic acid as described in Methods. 


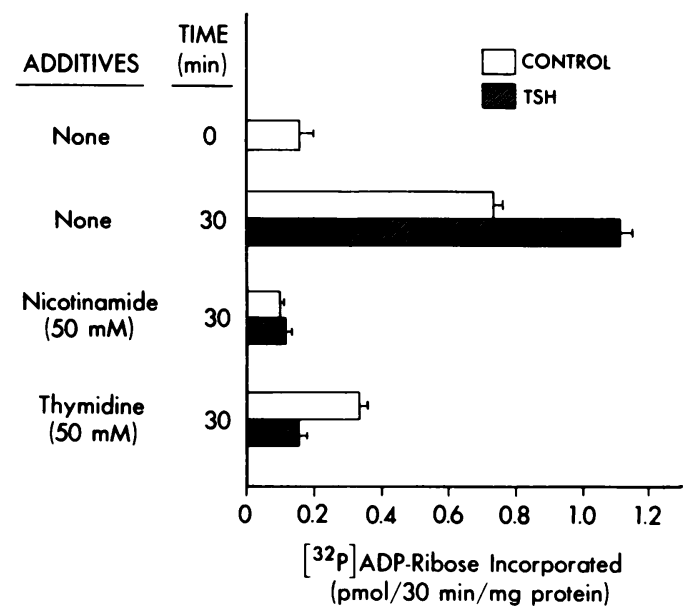

FIgURE 3 Effect of nicotinamide and thymidine on $\left[{ }^{32} \mathrm{P}\right]-$ ADP-ribose incorporation into thyroid cells. Cells $(1.12 \mathrm{mg}$ protein/tube) were incubated in $1 \mu \mathrm{M}\left[{ }^{32} \mathrm{P}\right] \mathrm{NAD}^{+}$for $30 \mathrm{~min}$ at $25^{\circ} \mathrm{C}$. When present, TSH was at a concentration of 100 $\mathrm{mU} / \mathrm{ml}$. Each bar represents the mean $\pm \mathrm{SE}$ of triplicate determinations.

lar concentrations of nicotinamide and thymidine blocked both basal and TSH-stimulated ADP-ribosylation of endogenous substrate in permeabilized, intact thyroid cells (Fig. 3).

Lack of effect of TSH on ADP-ribose degradation. TSH could increase net ADP-ribosylation of endogenous thyroid substrate either by increasing production or by inhibiting degradation of ADP-ribose. Permeabilized thyroid cells were therefore incubated in [ $\left.{ }^{32} \mathrm{P}\right] \mathrm{NAD}^{+}$for $45 \mathrm{~min}$ at which point $75 \mathrm{mM}$ nicotinamide together with $100 \mathrm{mU} / \mathrm{ml}$ TSH was added, the former to inhibit further ADP-ribose synthesis $(2,5)$. Control cells were treated with nicotinamide without TSH. Degradation of trichloroacetic acid-insoluble material was rapid ( $t 1 / 2$ of $\sim 6 \mathrm{~min}$ ) (Fig. 4). TSH was without effect on this rate of disappearance.

Effect of $B t_{2} c A M P$ on ADP-ribosylation. Desensitization of the cAMP response to TSH stimulation is one of the few effects of TSH not mediated by cAMP as a second messenger (20). Indeed, preexposure of thyroid cells to $0.1 \mathrm{mM} \mathrm{Bt}{ }_{2} \mathrm{cAMP}$ enhanced the subsequent cAMP response to TSH (20). It was therefore important to test whether $\mathrm{Bt}_{2} \mathrm{CAMP}$ altered ADPribosylation of endogenous thyroid substrate. Not only did $0.1 \mathrm{mM} \mathrm{Bt}_{2} \mathrm{cAMP}$ not mimic the effect of TSH, but significant inhibition of enzyme activity was observed (Fig. 5). At $0.5 \mathrm{mM}$, 3-isobutyl-1-methylxanthine has little effect on ADP-ribosylation (albeit of the poly variety) in $3 \mathrm{~T} 3$ cells (13\% inhibition at $1 \mathrm{mM}$ ) (4), but is a potent inhibitor of thyroid cell cAMP catabolism (12). This agent inhibited thyroid cell ADP-ribosylation by $60 \%$ (Fig. 5), providing further support that CAMP inhibits, rather than stimu-

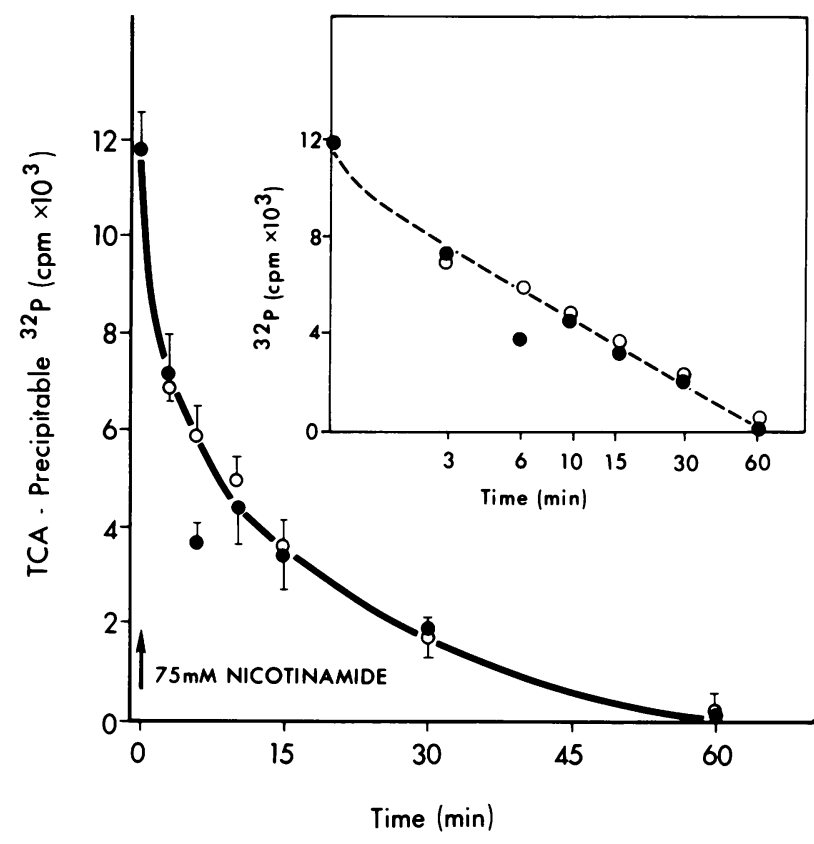

FIGURE 4 Lack of effect of TSH in altering the degradation rate of $\mathrm{NAD}^{+}$-derived, trichloroacetic acid-insoluble radiolabeled material. Cells made permeable to ${ }^{32} \mathrm{P}^{3} \mathrm{NAD}^{+}$were incubated for $45 \mathrm{~min}$ at $25^{\circ} \mathrm{C}$, as described in Methods. After adding nicotinamide (75 $\mathrm{mM}$ final concentration) to block the reaction, aliquots were incubated in the absence $(\bigcirc)$ or in the presence of TSH $(100 \mathrm{mU} / \mathrm{ml})(0)$. At the indicated times $0.2 \mathrm{ml}$ portions were taken and trichloroacetic acidprecipitable radioactivity was measured as previously described. Each point represents the mean $\pm S E$ of triplicate determinations. The insert indicates a semilogarithmic plot of the data.

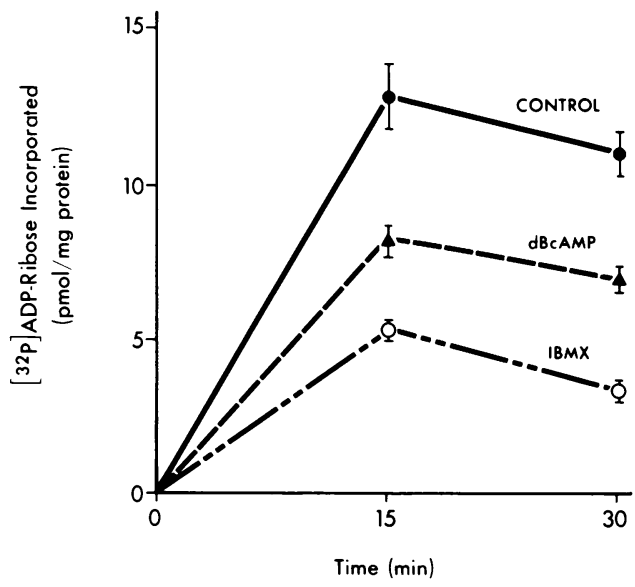

Figure 5 Effect of $\mathrm{Bt}_{2} \mathrm{cAMP}$ and isobutyl-methylxanthine on ADP-ribosylation in thyroid cells. Cells $(0.8 \mathrm{mg}$ protein/ tube) were incubated at $25^{\circ} \mathrm{C}$ for the indicated time periods in the presence of $\left.0.1 \mathrm{mM}{ }^{32} \mathrm{P}\right] \mathrm{NAD}^{+}$. Dibutyryl cAMP was present at a concentration of $10^{-4} \mathrm{M}$, and isobutylmethylxanthine at $0.5 \mathrm{mM}$. Each point represents the mean $\pm \mathrm{SE}$ of triplicate determinations. 
TABLE III

Dose-related Effect of $B t_{2} c A M P$ on ADP-ribose Incorporation into Thyroid Cellular Protein

\begin{tabular}{lcc}
\hline $\mathrm{Bt}_{2} \mathrm{CAMP}$ & ADP-ribose incorporation & Change \\
\hline & pmol/15 min/mg protein & $\%$ \\
0 & $0.52 \pm 0.07^{*}$ & \\
$0.1 \mathrm{mM}$ & $0.39 \pm 0.02$ & -25 \\
$10 \mu \mathrm{M}$ & $0.48 \pm 0.06$ & -8 \\
$1 \mu \mathrm{M}$ & $0.51 \pm 0.03$ & -2 \\
\hline
\end{tabular}

Cells $\left(1.6 \mathrm{mg} /\right.$ tube) were incubated with $1 \mu \mathrm{M}\left[{ }^{32} \mathrm{P}\right] \mathrm{NAD}^{+}$ for $15 \mathrm{~min}$.

* Mean \pm SD of triplicate determinations.

lates, ADP-ribosylation in the thyroid. Because this standard concentration of $\mathrm{Bt}_{2} \mathrm{cAMP}$ may have been excessive for permeabilized cells, perhaps masking a stimulatory affect at a more "physiological" concentration, the dose-response relationship of $\mathrm{Bt}_{2} \mathrm{cAMP}$ on ADP-ribosylation was examined (Table III). Inhibition was not observed at lower $\mathrm{Bt}_{2} \mathrm{cAMP}$ concentrations. Most important, however, at all concentrations $\mathrm{Bt}_{2} \mathrm{CAMP}$ was unable to mimic TSH stimulation of thyroid cellular ADP-ribosylation.

\section{DISCUSSION}

Our data demonstrate that the ADP-ribosylation process is, at least in part, under polypeptide hormone control-in this case, TSH. Previous data (21) have indicated that progesterone and estrogen alter poly(ADP-ribose) polymerase activity in the quail oviduct. Similar effects of other polypeptide hormones on their respective target tissues are clearly possible and amenable to investigation. The effect of TSH on ADP. ribosylation is not mediated by cAMP, raising the possibility of an alternative second messenger. TSH enhances ADP-ribose formation rather than decreases ADP-ribose degradation. Of interest is that the product $t_{1 / 2}$ of 6 min is similar to that reported by Gill (22) for (22) for poly(ADP-ribose).

The reason for the variability in the time of maximum TSH stimulation of ADP-ribosylation is not presently clear. It does not appear to be dependent on $\mathrm{NAD}^{+}$ substrate concentration (Fig. 1). Possible explanations include variable activity in different thyroids of the deribosylation mechanism that is proceeding unchecked simultaneously with increased ADP-ribosylation activity. The duration of cell permeability to $\mathrm{NAD}^{+}$after reconstitution of the cells in isotonic medium may also vary from one experiment to another.

The kinetics of the TSH-induced stimulation of net ADP-ribosylation are difficult to understand. Thus the TSH effect is seen primarily when the rate of accumulation of radiolabeled ADP-ribosylated material in the control cells is very low. Contributing to these com- plicated kinetics are, $(a)$ (there is a high rate of degradation of ADP-ribosylated material simultaneous with its synthesis), (b) the reaction is conducted in isotonic medium after intracellular introduction of $\mathrm{NAD}^{+}$under hypotonic conditions, and is therefore not at equilibrium, and $(c)$ there may be a lag-phase in the initiation of TSH action. Further studies will be necessary to elucidate these complex kinetics.

The question arises as to whether TSH stimulates the net formation of poly(ADP-ribose), mono-ADPribose, or both. Although the hypotonic shock method to introduce $\mathrm{NAD}^{+}$into cells, as used in this study, has been used extensively to measure poly(ADPribose)polymerase activity $(3,14,15)$, we observed that the major alkali and phosphodiesterase digestion product of cellular trichloroacetic acid-insoluble radioactivity (and the product whose concentration was increased by TSH) was 5'-AMP. Having determined that no residual labeled $\mathrm{NAD}^{+}$remained after extensive washing, the source of this $5^{\prime}$-AMP is likely to be mono(ADP-ribose). However we cannot exclude the possibility that mono(ADP-ribose) was a product of poly(ADP-ribose) broken into subunits during the analytical procedure. Phosphoribosyl-AMP was inconsistently observed in small amounts $(<10 \%)$, and its concentration was not affected by TSH stimulation. Consistent with our data, Maayan (23) demonstrated nearly $20 \mathrm{yr}$ ago that nicotinamide in concentrations similar to those we used, inhibited $\mathrm{NAD}^{+}$glycohydrolase activity in thyroid homogenates. The most likely explanation for our data is that TSH stimulates thyroid $\mathrm{NAD}^{+}$glycohydrolase and ADP-ribosyl transferase activity in the thyroid by a cAMP-independent mechanism.

In coming to this conclusion it is important to consider an effect of TSH on the specific activity of cellular $\mathrm{NAD}^{+}$, or substrate availability, rather than on enzyme activity. Fortunately, as shown in previous studies (3), these complexities are avoided by the use of the permeabilized cell system that eliminates separate intra- and extracellular pools. The permeabilized cells contribute very little $\mathrm{NAD}^{+}$to the reaction mixture, and, as confirmed herein, formation of precipitable ADP-ribose is dependent upon the amount of $\mathrm{NAD}^{+}$added to the incubation mixture and not on endogenous cellular $\mathrm{NAD}^{+}$content. Thus, addition of $\mathrm{NAD}^{+}$to the incubation at a concentration of $1 \mathrm{mM}$ is $\sim 1,000$-fold greater than the estimated $\mathrm{NAD}^{+}$contribution by the cells to the medium (3). TSH also does not enhance transport of labeled NAD ${ }^{+}$ into cells not subjected to hypotonic shock, as evidenced by a complete lack of incorporation of radioactivity into cellular material in the presence of TSH (Fig. 1).

Another important consideration in interpreting our data was that TSH-induced ADP-ribosylation was due 
to intrinsic $\mathrm{TSH} \mathrm{NAD}^{+}$glycohydrolase activity, for which there is preliminary evidence (16). However, despite much effort we have not been able to observe such activity in our cell-free system. In addition, as previously mentioned, in the presence of cells not made permeable, TSH does not increase incorporation or radioactivity from labeled $\mathrm{NAD}^{+}$(Fig. 1). The reasons for this difference are unclear, but may relate to different TSH preparations used, different incubation conditions, and a different system of analysis.

These data are consistent with previously obtained evidence using inhibitors of ADP-ribosylation reactions that the ADP-ribosylation process plays a role in TSH desensitization in thyroid cells. The timecourse of TSH enhancement of ADP-ribosylation is also similar to the onset of TSH desensitization (12). Both phenomena also appear to be cAMP independent. It should also be noted that ADP-ribosylation (albeit poly-) is of importance in the modulation of nuclear and translational activities, whereas TSH desensitization is dependent on new protein synthesis (20). The scenario is now unfolding of hormonal modulation of cellular function by a variety of cAMP-independent mechanisms, now including ADP-ribosylation.

\section{ACKNOWLEDGMENTS}

The expert secretarial assistance of Mrs. Peggy Mathews is gratefully acknowledged. We thank Dr. John Widdicombe for generously providing us with dog thyroid glands.

This work was supported by National Institute of Arthritis, Metabolism, and Digestive Diseases grant AM 19289-05 and the Medical Research Service of the Veterans' Administration. Dr. Rapoport is the recipient of National Institutes of Health Career Development Award AM 00500.

\section{REFERENCES}

1. Filetti, S., N. A. Takai, and B. Rapoport. 1980. ADPribosylation: a new mechanism by which hormonal (thyrotropin) desensitization is produced in target tissue. Clin. Res. 28: 478a. (Abstr.)

2. Preiss, J., R. Schlaeger, and H. Hilz. 1971. Specific inhibition of poly ADP-ribose polymerase by thymidine and nicotinamide in HeLa Cells. FEBS (Fed. Eur. Biochem. Soc.) Lett. 19: 244-246.

3. Berger, N. A., G. Weber, and A. S. Kaichi. 1978. Characterization and comparison of poly(adenosine diphosphoribose) synthesis and DNA synthesis in nucleotidepermeable cells. Biochim. Biophys. Acta. 519: 87-104.

4. Levi, V., E. L. Jacobson, and M. K. Jacobson. 1978. Inhibition of poly(ADP-ribose) polymerase by methylated xanthines and cytokinins. FEBS (Fed. Eur. Biochem. Soc.) Lett. 88: 144-146.

5. Moss, J., S. J. Stanley, and P. A. Watkins. 1980. Isolation and properties of an NAD- and guanidine-dependent ADP-ribosyltransferase from turkey erythrocytes. J. Biol. Chem. 255: 5838-5840.
6. Filetti, S., N. A. Takai, and B. Rapoport. 1981. Prevention by nicotinamide of desensitization to thyrotropin stimulation in cultured human thyroid cells. J. Biol. Chem. 256: 1072-1075.

7. Hilz, H., and P. Stone. 1976. Poly(ADP-ribose) and ADP.ribosylation of proteins. Rev. Physiol. Biochem. Exp. Pharmacol. 76: 1-58.

8. Hayaishi, O., and K. Ueda. 1977. Poly(ADP-ribose) and ADP-ribosylation of proteins. Annu. Rev. Biochem. 46: 95-116.

9. Durkacz, B. W., O. Omidiji, D. A. Gray, and S. Shall. 1980. (ADP-ribose) $)_{n}$ participates in DNA excision repair. $\mathrm{Na}$ ture (Lond.). 283: 593-596.

10. Pappenheimer, A. M., Jr. 1977. Diphtheria toxin. Annu. Rev. Biochem. 46: 69-94.

11. Moss, J., and M. Vaughan. 1979. Activation of adenylate cyclase by choleragen. Annu. Rev. Biochem. 48: 581600.

12. Rapoport, B. 1976. Dog thyroid cells in monolayer tissue culture: adenosine $3^{\prime}, 5^{\prime}$-cyclic monophosphate response to TSH. Endocrinology. 98: 1189-1197.

13. Lowry, O. H., N. J. Rosebrough, A. Farr, and R. J. Randall. 1951. Protein measurement with the Folin phenol reagent. J. Biol. Chem. 193: 265-275.

14. Skidmore, C. J., M. I. Davies, P. M. Goodwin, H. Halldorsson, P. J. Lewis, S. Shall, and A-A Zia'ee. 1979. The involvement of poly(ADP-ribose) polymerase in the degradation of NAD caused by $\gamma$-radiation and N-methylN-nitrosourea. J. Biochem. 101: 135-142.

15. Halldorsson, H., D. A. Gray, and S. Shall. 1978. Poly(ADP-ribose)polymerase activity in nucleotide permeable cells. FEBS (Fed. Eur. Biochem. Soc.) Lett. 85: 349-352.

16. Oppenheimer, N. H. 1978. Structural determination and stereospecificity of the choleragen-catalyzed reaction of $\mathrm{NAD}^{+}$with guanidines. J. Biol. Chem. 253: 4907-4910.

17. Moss, J., and M. Vaughan. 1977. Mechanism of action of choleragen. Evidence for ADP-ribosyltransferase activity with arginine as an acceptor. J. Biol. Chem. 252: 2455-2457.

18. Moss, J., P. S. Ross, G. Agosto, S. Birken, R. E. Canfield, and M. Vaughan. 1978. Mechanism of action of choleragen and the glycopeptide hormones: is the nicotinamide adenine dinucleotide glycohydrolase activity observed in purified hormone preparations intrinsic to the hormone? Endocrinology. 102: 415-419.

19. Stone, P. R., W. S. Lorimer III, and W. R. Kidwell. 1977. Properties of the complex between histone $\mathrm{Hl}$ and poly(ADP-ribose) synthesised in HeLa cell nuclei. Eur. J. Biochem. 81: 9-18.

20. Rapoport, B., and R. J. Adams. 1976. Induction of refractoriness to thyrotropin stimulation in cultured thyroid cells: dependence on new protein synthesis. J. Biol. Chem. 251: 6653-6661.

21. Muller, W. E. G., A. Totsuka, I. Nusser, J. Obermeier, H. J. Rhode, and R. K. Zahn. 1974. Poly(adenosine diphosphate ribose) polymerase in quail oviduct. Changes during estrogen and progesterone induction. Nucleic Acids Res. 1: 1317-1327.

22. Gill, D. M. 1972. Poly(adenosine diphosphate ribose) synthesis in soluble extracts of animal organs. J. Biol. Chem. 247: 5964-5971.

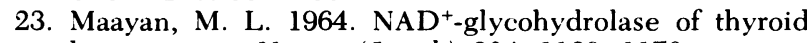
homogenates. Nature (Lond.). 204: 1169-1170. 